UDC 338.27

DOI: https://doi.org/10.32782/2413-9971/2020-30-34

Temchyshyna Yulia

Candidate of Economic Sciences, Associate Professor, National University of Food Technologies

Siderova Anastasiia

Student

National University of Food Technologies

Темчишина Ю. Л. кандидат економічних наук, дочент, Національний університет харчових технологій Сідерова А. П. студентка

Національного університету харчових технологій

\title{
SYSTEM-INFORMATION MODERNIZATION OF SUSTAINABILITY MANAGEMENT AND DEVELOPMENT OF FOOD INDUSTRY ENTERPRISES
}

Summary. The article discusses the economic sustainability and progressive development of the food industry. The future of the national economy depends on the ability to sustainable functioning of manufacturing enterprises in today's economic environment, the key challenges for which are fierce competition and global trends in the market. In this context, there is a need for scientific research on the latest approaches to the formation and assessment of a business entity's potential resilience, its analysis and forecasting of its progressive development in order to achieve international competitiveness. In research, the systemic object is the resource resilience of the enterprise in the components that form it and ensure the progressive development of the enterprise. Generalization of scientific searches of resource direction of management of formation of potential of effective functioning and upward development of enterprises allows to allocate the following composition of resources for the characterization of complex system object «stability of enterprise»: financial, logistical, labor, organizational, innovative, information, intellectual. The intellectual support of the enterprise has a great influence on the successful solution of problems of the modern enterprise. The stability of a modern manufacturing enterprise and its upward development in achieving international competitiveness is predominantly based on the resource potential, both in the starting state of the enterprise and the dynamics of intermediate perspective states. Effective management of economic stability and upward development of an enterprise on the basis of a resource complex is accompanied by its evaluation, analysis and forecasting using a large variety of absolute and relative indicators.

Key words: enterprise sustainability, economic sustainability, financial sustainability, progressive development, accounting and analytical support, systems theory, systems analysis.

Introduction and formulation of the problem. The nature and orientation of the development of the national economy is a subject of great attention of scientists. The future of the national economy depends on the ability to sustainable functioning of manufacturing enterprises in today's economic environment, the key challenges for which are fierce competition and global trends in the market. In this context, there is a need for scientific research on the latest approaches to the formation and assessment of a business entity's potential resilience, its analysis and the forecasting of its progressive development in order to achieve international competitiveness. Therefore, the axiom is the assumption that the long-term development of a modern enterprise is a regular and continuous process of quantitative and qualitative changes in the states of functioning of the enterprise in the direction of reaching a higher level. The higher level is formed under the influence of factors of internal and external environment and the starting state in its achievement is the existing potential of the enterprise, and the result is the optimum level of competitiveness of the business entity.

Scientific research in the economic sustainability and progressive development of the food industry is particularly relevant today.

A survey based on statistical yearbooks has shown that the most positive developments in the food industry in recent years have been observed in Poltava, Cherkasy, Kyiv, Kirovohrad regions, as evidenced by the increase in their share in national food production.

According to the prevailing scientific opinion, the progressive development of modern food industry enterprises requires the formation of a powerful resource potential, the analysis of the environment, the analysis of internal reserves and the possibilities of their practical realization. Among the list of economic resources of industrial enterprises (technical, material, financial, labor, intangible, informational), many scientists emphasize on the increasing of the role and place of information and intellectual resources in information and analytical technologies for supporting managerial decisions. In order for leading food companies to become fullfledged players in the European and international markets, it is necessary to consider more deeply the economic category of «enterprise sustainability» as a basis for progressive development in modern scientific research. In this regard, in our view, both general subject and applied industry research should be based on a well-defined fundamentalization. In our study, the element of fundamentalization lies in the starting effort, which is based on systems theory, systemic approach, and views the enterprise as an open socio-economic system with certain subsystems of complex objects requiring managerial influence. Hypothetically, such complex entity can be the enterprise sustainability.

Analysis of recent research and publications. Significant contribution to the theoretical foundations of the study of the economic sustainability of the enterprise, its evaluation, especially in the aspect of financial sustainability management and its accounting and analytical support, was made by wellknown domestic and foreign scientists: I. Blank, Y. Brigham, D. Van Horn, G. Savitskaya, K. Bezverkhy [2], M. Kizim [8], V. Savchuk [17], G. Kireytsev, L. Kostyrko [10], A. Shaykan, 
E. Kostyukova, M. Resler, M. Ishchenko, I. Manko, OTridid [19], L. Lakhtionova [12], etc.

Intensive development in the last decade has gained scientific research on the use of systems theory, systems analysis, systems approach and modern information systems and technologies in solving problems of enterprise management and their subsystems.

Rational decisions in this direction have been presented in the works of both foreign and domestic scientists: A. Lyapunov [13], V. Basilevich, V. Leontva, L. Melnik [14], V. Andriychuk, A. Marshall, J. Galbraith, V. Radionova [16], S. Knyazev [9], Y. Lysenko [15], etc.

It is worth noting, that thorough scientific research in the key subject areas that produce information, such as accounting and auditing, statistics, economic and financial analysis, economic and mathematical modeling, significant information potential for improving enterprise management, its subsystems and potential for progressive development is created. However, problems regarding the development of tools for qualitative multiplication and productive use of the intellectual and information potential of modern enterprises remain. In this sense, world practice proves that powerful capabilities are embedded in modern information systems and technologies. They are not fully implemented in domestic practice.

The purpose of the research is to reveal the newest theoretical aspects of managing the formation of sustainability of a manufacturing enterprise on a resource paradigm in combination with the possibilities of their practical implementation by means of tools of modern information technologies.

Results of the research. The notion of sustainability was borrowed by economic science from systems theory, when economic objects were regarded as complex and diverse economic systems [13].

In the works of systems theory and systems analysis different definitions of the term system are provided. Thus, in encyclopedic literature, the system is understood as a set of interrelated elements that form integrity and unity. The concept of «integrity» means completeness and accuracy, and the integrity of information is the assurance of the accuracy and completeness of information [18].

In the common view of the authors of extensive research on the theory of socio-economic systems [3; 14], the concept of «system» is interpreted as a holistic complex of interdependent components, which has a special unity with the external environment and is a subsystem of a higher order. Characteristic features of socio-economic systems are the following:

- complexity of problems and necessity of their definition in unity of technical, economic, social, psychological, managerial and other aspects;

- increase in the number of connections between objects;

- dynamics of changing situations;

- scarcity of all types of resources (material, labor, financial, etc.);

- strengthening the role of the human factor in governance and others.

These features make it inevitable to apply a systematic approach, because only on the basis of it the quality of management decisions can be ensured. The systematic approach is based on certain principles, among which, in our opinion, the integrity and structuring are fundamental are present. Integrity allows to consider the system as a whole and at the same time as a subsystem for higher levels. Structuring allows to analyze the elements of the system in their relationship. The system element has all the features of the system and is considered a system object.

In the generalized view of scientists, the system control must have the following basic properties [3]:
- the object is created for a specific purpose and in the process of achieving these goal functions and changes;

- system object is a managed system, the system object uses information about its own state, the state of the environment, and simulates the behavior of the object in the external environment. An object consists of interdependent components that perform certain functions in its system. All the components of a system object, when they co-operate, provide a new property that is not owned separately by each component.

In our research, the systemic object is the resource resilience of the enterprise in the components that form it and ensure the progressive development of the enterprise.

Extensive analysis of professional publications devoted to the problems of enterprise sustainability has shown that scientists pay the most attention to the content, evaluation and management analysis of financial sustainability.

The scientist $\mathrm{O}$. Tridid in his scientific work considers the financial sustainability of the enterprise as a process continuous and adapted to the space and time changes of transformation of capital (sources of financing of economic activity) into capital goods (material resources, finished goods, cash) [19].

In the research of $\mathrm{O}$. Kizim and L. Kostyrko the sustainability of the enterprise is defined as a financial concept. They interpret sustainability as the ability of an enterprise to change the condition and volume of finance with a minimum of risk and loss, with economic rewards $[8,10]$.

O. Kuzmin, in defining the concept of «enterprise sustainability», argues that the financial sustainability of the enterprise characterizes the efficiency of operational, investment and financial development, contains the necessary information for investors, suppliers, owners, as well as it is the basis for the functioning of the economic system in the conditions of instability of economic processes, uncertainty, dynamic economic environment. That is, its analysis makes it possible to determine the perspective financial capabilities of the enterprise [11].

L. Lakhtionova gives wide and deep understanding of the category of «sustainability» and «financial sustainability» in her monograph. In her scientific work, the financial sustainability of an entity is a state of financial resources, in which a market and mixed economy entity, which is freely maneuver cash, is able to ensure the continuous processes of its operating, financial and investment activities, and expenses for their expansion and updating and appearance of their new directions and components through their effective use [12, p. 71].

In justifying her point of view, L. Lakhtionova relies on the resource base of financial sustainability and outlines the following key arguments:

- it is a state of financial resources, because it is a matter of resource financial sustainability;

- the entity must freely maneuver the funds over the particular condition of the financial resources;

- a market economy entity must use cash to ensure continuous operations, which, in accordance with international accounting and financial reporting standards and national accounting standards, consist of processes of operational, financial and investment activities as its main types, therefore, in the modern interpretation of the concept of financial sustainability is necessary to focus on all types of economic activities of the entity.

It is worth noting that in her monograph L. Lakhtionova explored more than three dozen group opinions reflected in a wide range of educational literature and scientific publications, regarding the definition of «financial sustainability» and its argumentation. Using the resource approach, the author proposes to allocate: financial - resource or simple financial sustainability and non-financial - resource (intangible - material-labor) stability, which represents the optimal composition, 
structure and ratio of labor, tangible and intangible resources of the economic entity contributing to economy costs [12].

Our research has shown that in a number of scientific works, financial sustainability is equated with financial stability. However, if making assumptions and analogies with biological systems that a modern production enterprise is not only an open system, but also a living organism, the prerequisite of life of which is stability and sustainability, on the basis of systems theory and systemic approach, then the concept of «stability» and «sustainability» should not be identified. In our view, the notion of «stability» is quite indicative in medical science and practice. Thus, in the diagnosis of human health the following concepts are distinguished:

a) the condition is stably severe;

b) the condition is stable without symptoms of complication of gravity.

In this connection, it is reasonable to conclude that stability with respect to biological systems is «survivability» or «endurance». The fundamental difference between the functions of endurance (stability) and resilience is that endurance allows the system to survive, and resilience creates the conditions for development. If you modify these characteristics to an enterprise that operates in a dynamic environment with risks, then the economic condition of the enterprise is «stable severe» requiring diagnostics regarding the probability of bankruptcy, and a stable state without symptoms of complication has a sufficient probability of remedial formation of the necessary stability and ability for upward development.

In our view, the resource interaction of stability, sustainability and progressive development (economic growth) is the only continuous vector chain: stability - sustainability growth - stability - ..

In general research, financial sustainability is the dominant of enterprise sustainability, as is the dominant in productive management accounting and analytical support, based on reporting by national and international standards. Based on the current reporting and information capacity of the reports (balance sheet, income statement, cash flow statement, equity report), such top-level analysis of the dynamics and sustainability can be provided as: horizontal and vertical balance analysis; property analysis; analysis of relative liquidity indicators; analysis of relative indicators of financial independence; analysis of the structure and dynamics of financial results; profitability analysis; business activity analysis; market value analysis.

However, in our view, the dominance of financial sustainability is a prerequisite, but not sufficient to manage the resilience of an enterprise as a complex systematic entity. Therefore, a complete information resource characteristic (single information field) of the object «enterprise sustainability», as the starting potential of dynamism and progressive development of the enterprise, is ensured by the inclusion of all basic resources in the management complex to ensure their synergistic interaction and efficiency. Generalization of scientific searches of resource direction of management of potential formation of effective functioning and upward development of enterprises allows to allocate the following composition of resources for the characterization of complex system object «stability of enterprise»: financial, logistical, labor, organizational, innovative, information, intellectual. The new elements in this list are information and intellectual resources.

The level of information support, its completeness and reliability, the level of development of information and communication technologies, characterize information resources. In the encyclopedic interpretation, the information resources are the set of knowledge, ideas, information, etc., which are gradually accumulated in the process of development of sci- ence and practical activity of people and are used in all spheres of public life [6]

The intellectual potential (intellectual support) of the enterprise has a great influence on the successful solution of problems of the modern enterprise.

Scientist A. Antonov interprets intelligence as the ability to generate new information, i.e., information that was not on the object of the system, but has been able to become a commodity [1].

The formation of an intellectual resource in a manufacturing enterprise is accomplished by transforming the intelligence of the management personnel of the enterprise into intellectual capital, which is transformed into intellectual assets and ultimately creates intellectual property. Therefore, it can be considered that the intellectual resources of the enterprise include intellectual property, accumulated or acquired abilities, competencies of staff, formed business network, investments in human capital development.

Effective management of economic stability and upward development of an enterprise on the basis of a resource complex is accompanied by its evaluation, analysis and forecasting using a large variety of absolute and relative indicators, which require their certain systematization in order to facilitate the use and comprehension of the obtained results, to formulate correct analyzes scientifically substantiated proposals. This requires the use of modern information systems and information technologies in economic practice.

At the present stage, that is, the stage of informatization of society in scientific research, attention of scientists is emphasized on the expediency of introducing management decision support systems into economic practice.

The content of the decision support system in encyclopedic and dictionary publications is defined as: a system that provides the ability to study the status, predict development and evaluate possible behaviors based on the analysis of statistics that reflect the results of the organization (enterprise) over time. Such systems use modern database technologies, OLAP (interactive, analytical data processing), data warehouses, advanced analysis and data visualization [18].

In research to improve decision support systems, there has been an increasing tendency to introduce into their structure an intellectual component - a knowledge base that is constructed using certain methods of presenting and seeking knowledge.

To develop the structure of intelligent decision support systems (IDSS) it is necessary to distinguish such components [7].

1. Database, which is designed to store, manage, display and analyze data. The system uses two types of sources:

- external sources (official data of domestic and international institutions, data of commodity, stock, currency markets);

- internal sources (financial and non-financial reporting, management accounting data) that form the key performance indicators for a particular entity.

2. Knowledge base, which is an array of information in a form suitable for logical and semantic processing by appropriate software. It is believed that knowledge bases allow to present any knowledge that a specialist may encounter in their work in their natural form.

3. Model database is a system that includes a set of models to provide user requests and solve the necessary list of practical tasks.

4. User interface is intended for dialogue with the person making management decision both at the stage of information input and at the stage of output of results.

IDSS is a multifunctional and dynamic system that is potentially capable and aimed at solving important practical problems of control, analysis, budgeting, forecasting, planning, economic and statistical modeling, etc. 
In our opinion, in the structure of IDSS it is necessary to have a module for managing the object «enterprise sustainability» based on our researched and scientifically grounded resource approach (R). Using the tools of modern information technology, the process of managing the object «enterprise sustainability» can be formally characterized by a sequence

$$
<\mathrm{S}_{0}, \mathrm{~S}_{\mathrm{m}}, \mathrm{O}, \mathrm{R}_{1}, \mathrm{R}_{2}, \ldots \mathrm{R}_{\mathrm{i}} \ldots \mathrm{R}_{\mathrm{n}}>\text {. }
$$

Such a sequence is regarded as the process of reaching the goal directly with the use of the operator $\mathrm{O}$ - the transition from the initial state $S_{0}$ to the final state $S_{m}$.

It should be noted that operator $\mathrm{O}$ requires the management of all components, which are a systematic resource for the sustainability of the enterprise. In our study, such a sequence includes financial, logistical, labor, innovation, information, organizational, and intellectual resources.

The transition of the control object from state $\mathrm{S}_{0}$ to state $\mathrm{S}_{\mathrm{m}}$ is not instantaneous, it is designed for a certain period of time. Therefore, quantitative and qualitative characteristics of each type of resources obtained by information technology, in the intervals of observation will allow to:

- identify the formed disparities between the components of a complex resource management object;

- find out to what extent the industrial enterprise resource complex in the industry dimension is adequate to the goals and objectives of formation of sustainability and opportunities of progressive development;

- identify priorities and opportunities to achieve synergistic interaction between all types of resources;

- integrate differentiated quantitative and qualitative indicators of all resource components into a summarized indicator (integrated) for monitoring, analysis, forecasting and planning;

- calculate the forecast (potential stability) for different scenarios of dynamics of quantitative and qualitative indicators, differentiated by resource components, and summarizing integral indicators.

It is also important to note that experts in modern information technology emphasize the need to replenish traditional tools of analytical and forecasting calculations with the latest tools, an example of which is: the use of nonlinear dynamic statistics, discrete logic, fractal analysis, fuzzy set theory; hybrid neuro - fuzzy systems, cloud technologies, etc.
To improve the management of resource resilience formation and the progressive development of an industrial enterprise on its basis, it is advisable, in our view, to use the latest elements of information intellectualization by processing knowledge and reasoning on knowledge, processing fuzzy information based on fuzzy set theory and using appropriate software (Statistica Neural Networks, Neuroshell and others).

ERP systems (Enterprise Resource Planning System) are also widely used in corporate information systems.

Thus, the use of modern innovative information technology allows to obtain a new level of management of the formation of the sustainability potential of a manufacturing enterprise as a starting base for its progressive development.

Conclusions. The stability of a modern manufacturing enterprise and its upward development in achieving international competitiveness is predominantly based on the resource potential, both in the starting state of the enterprise and the dynamics of intermediate perspective states. A system - object stability is practically important to consider. This will allow us to achieve synergistic interaction of the constituent elements of the object through time and space by applying the latest information technologies.

Dozens of absolute indicators and coefficients, which are important in managing the sustainability of the enterprise, according to the arguments of many scientists, are impossible to organize in logic and simple analytical methods in such a way as to avoid errors of the final analytical and prognostic evaluation, which is why modern management information systems with information and technology are the newest resource that should be formed both at the large corporate enterprises and small enterprises with a certain number of employees.

For large and medium-sized enterprises modern information system should be formed and its intelligent information technologies should be based on the knowledge base. Simplified information system, which includes subsystems: information, legal, mathematical, software, organizational-technical, which are necessary and sufficient for autonomous management of a small enterprise or cluster of small enterprises.

Further studies will be related to the formation of a comprehensive accounting, analytical and intellectual information support for the systematic management of the sustainability of food industry in the conditions of turbulence of the market environment.

\section{References:}

1. Antonov V. (2005) Intelektualna vlasnist i kompiuterne avtorske pravo [Intellectual property and computer copyright]. Kyiv: CST. (in Ukrainian)

2. Bezverkhy K. (2014) Informatsiinyi kompleks oblikovoi systemy ta zvitnist v Ukraini [Accounting Information System Complex and Reporting in Ukraine]: monograph. Kyiv: "Center for Educational Literature". (in Ukrainian)

3. Bidnyak M., Vlasenko D. (2002) Pryntsypy modeliuvannia system, shcho rozvyvaiutsia [Principles of Modeling Developing Systems]. Bulletin of NTU, no. 7, pp. 265-267.

4. Volokitya A., Mukhin V., Steshin V. (2011) Spetsyfika informatsiinykh system na osnovi tekhnolohii cloud computing [Specificity of information systems based on cloud computing technology]. Journal of Chernihiv State Technological University, no. 4(53), pp. 176-184. Available at: https://ts-vistnic.stu.cn.ua/tmppdf/1226.pdf (accessed 18 January 2020).

5. Grossul V. (2007) Sotsialno-ekonomichna stiikist pidpryiemstva: teoretyko - metodolohichni zasady [Socio-economic stability of the enterprise: theoretical and methodological foundations]: monograph. Kharkiv: Kharkiv State University of Food and Trade. (in Ukrainian)

6. P. Kraineva (ed.) (2012) Entsyklopediia intelektualnoi vlasnosti [Intellectual property encyclopedia]. Kyiv: Start-98. (in Ukrainian)

7. ZamulaA. (2013) Razrabotka intellektual'noy sistemy podderzhki prinyatiya resheniy dlya upravleniya bankovskoy deyatel'nost'yu [Development of an intelligent decision support system for banking management]. Artificial Intelligence, no. 1, pp. $117-122$.

8. Kizim M., Zabrodsky V, Zinchenko V., Kopchak Y. (2003) Otsinka i diahnostyka finansovoi stiikosti pidpryiemstva [Evaluation and diagnostics of financial stability of the enterprise]: a monograph. Kharkiv: VD INZHEK. (in Ukrainian)

9. Knyazev S., Shrubenko A. (2007) Intellektualizatsiya - sterzhnevaya osnova razvitiya ekonomiki i upravleniya [Intellectualization - the core basis of economic and management development]. Management problems, no. 3(24), pp. 16-25.

10. Kostyrko L. (2012) Finansovyi mekhanizm staloho rozvytku pidpryiemstv: stratehichni oriientyry, systemy zabezpechennia, adaptatsiia [Financial Mechanism of Sustainable Development of Enterprises: Strategic Guidelines, Systems of Provision, Adaptation]: Monograph. Lugansk: Knowledge Publishing House. (in Ukrainian) 
11. Kuzmin O., Melnyk O. (2007) Osnovy menedzhmentu [Fundamentals of management]: Textbook. Kyiv: Akademvidav. (in Ukrainian)

12. Lakhtionova L. (2013) Analiz finansovoi stiikosti subiektiv pidpryiemnytskoi diialnosti [Analysis of financial stability of business entities]: monograph. Kyiv: Knowledge of Ukraine. (in Ukrainian)

13. Lyapunov A. (1950) Teoriya ustoychivosti [Theory of stability]. Moscow: Publishing House of the USSR Academy of Sciences. (in Russian)

14. Melnik L. (2012) Teoryia samoorhanyzatsyy ekonomycheskykh system [Theory of self-organization of economic systems]: monograph. Sumy: University Book. (in Ukrainian)

15. Lysenko Yu., Bizyanov E., Khmelev A. (2012) Nechetkie modeli i neyronnye seti v analize i upravlenii ekonomicheskimi ob'ektami [Fuzzy models and neural networks in the analysis and management of economic objects]. Donetsk: South-East. (in Ukrainian)

16. Rodionov V. (2012) Regulirovanie dinamiki sotsial'no-ekonomicheskikh sistem v usloviyakh rosta nestabil'nosti vneshney i vnutrenney sredy [Regulation of the dynamics of socio-economic systems in conditions of increasing instability of the external and internal environment]. St. Petersburg: Nestor-History. (in Russian)

17. Savchuk V. (2005) Prakticheskaya entsiklopediya. Finansovyy menedzhment [Practical Encyclopedia. Financial management]. Kyiv: The publishing house "Maximum". (in Ukrainian)

18. Osaulenko O., Vasenko O., Pugachev M. and others (in a row. dr. Prof., Prof., Corresponding Member of NAS of Ukraine O.G. Osaulenko) (2012) Statystychnyi slovnyk [Statistical dictionary]. Kyiv: SE "Inform. - analyte. Agency". (in Ukrainian)

19. Tridid O. (2010) Otsiniuvannia finansovoi stiikosti pidpryiemstva [Evaluation of financial stability of the enterprise]: a monograph. - Kyiv: USB NBU. (in Ukrainian)

20. McCloskey D. (2016) Max U versus Humanomics: A Critique of Neoinstitutionalism. Journal of Institutional Economics, vol. 12, no. 1 , pp. 1-27.

\section{Список використаних джерел:}

1. Антонов В.М. Інтелектуальна власність і комп’ютерне авторське право. Київ, 2005. 1520 с.

2. Безверхий К.В. Інформаційний комплекс облікової системи та звітність в Україні : монографія. Київ : «Центр учбової літератури», 2014. $184 \mathrm{c}$.

3. Бідняк М.Н., Власенко Д.О. Принципи моделювання систем, що розвиваються. Вісник НТУ. 2012. №7. С. $265-267$.

4. Волокитя А., Мухін В., Стешин В. Специфіка інформаційних систем на основі технології cloud computing. Bicник Чернігівського державного технологічного університету. 2011. №4 (53). C. 176-184. URL: https://ts-vistnic.stu.cn.ua/tmppdf/1226. pdf (дата звернення: 18.01.2020).

5. Гросул В.А. Соціально - економічна стійкість підприємства: теоретико-методологічні засади : монографія. Харків : Харківський державний університет харч. та торгівл., 2007. 303 с.

6. Енциклопедія інтелектуальної власності / за ред. проф. П.П.Крайнева. Київ: Старт - 98, 2012. 660 с.

7. Замула А.А. Разработка интеллектуальной системы поддержки принятия решений для управления банковской деятельностью. Искусственный интелект. 2013. № 1. С.117-122.

8. Оцінка і діагностика фінансової стійкості підприємства : монографія / М.О.Кизим та ін. Харків : ВД «ІНЖЕК», 2003. 144 с.

9. Князев С.Н., Шрубенко А.Г. Интеллектуализация - стержневая основа развития экономики и управления. Проблемы управления. 2007. № 3(24). С. 16-25.

10. Костирко Л.А. Фінансовий механізм сталого розвитку підприємств: стратегічні орієнтири, системи забезпечення, адаптація : монографія. Луганськ : Вид-во «Ноулідж», 2012. 474 с.

11. Кузьмін О.С., Мельник О.Г. Основи менеджменту. Київ, Академвидав, 2007. 462 с.

12. Лахтіонова Л.А. Аналіз фінансової стійкості суб'єктів підприємницької діяльності : монографія. Київ : Знання України, 2013. $1091 \mathrm{c}$.

13. Ляпунов А.М. Теория устойчивости. Москва, 1950. 472 с.

14. Мельник Л.Г. Теория самоорганизации экономических систем : монография. Сумы : Университетская книга, 2012.439 с.

15. Нечеткие модели и нейронные сети в анализе и управлении экономическими объектами / Ю.Г.Лысенко и др. ; под ред. чл.-кор. НАН Украины, д-ра экон. наук, проф. Ю.Г.Лысенко. Донецк: Юго-Восток, 2012. 388 с.

16. Родионов В.Г. Регулирование динамики социально-экономических систем в условиях роста нестабильности внешней и внутренней среды. Санкт-Петербург, 2012. 432 с.

17. Савчук В.П. Практическая энциклопедия. Финансовый менеджмент. Київ, 2005. 884 с.

18. Статистичний словник / О.Г.Осауленко та ін. ; за ред. д-ра держ. упр., проф., член-кор НАН України О.Г. Осауленка. Київ : ДП «Інформ.-аналіт. агенство», 2012. 498 с.

19. Тридід О.М. Оцінювання фінансової стійкості підприємства : монографія. Київ : УСБ НБУ, 2010. 143 с.

20. McCloskey D. Max U versus Humanomics: A Critique of Neoinstitutionalism. Journal of Institutional Economics. 2016. Vol. 12. № 1. P. 1-27.

\section{СИСТЕМНО-ІНФОРМАЦІЙНА МОДЕРНІЗАЦІЯ УПРАВЛІННЯ СТІЙКІСТЮ ТА РОЗВИТКОМ ПІДПРИЕМСТВ ХАРЧОВОЇ ПРОМИСЛОВОСТІ}

Анотація. У статті розглядається економічна стійкість та прогресивний розвиток підприємств харчової промисловості. Майбутнє національної економіки залежить від здатності до сталого функціонування виробничих підприємств у сучасних економічних умовах, для яких ключовими викликами є жорстка конкуренція та глобальні тенденції на ринку. У цьому контексті виникає потреба у наукових дослідженнях новітніх підходів до формування та оцінки потенційної стійкості суб'єкта господарювання, його аналізу та прогнозування його прогресивного розвитку 3 метою досягнення міжнародної конкурентоспроможності. У дослідженні системним об'єктом є ресурсна стійкість підприємства. Узагальнення наукових пошуків дозволяє виділити наступний склад ресурсів для характеристики складного системного об'єкта «стабільність підприємства»: фінансовий, матеріально-технічний, трудовий, організаційний, інноваційний, інформаційний, інтелектуальний. Інтелектуальна підтримка підприємства має великий вплив на успішне вирішення проблем сучасного підприємства. Стабільність сучасного підприємства-виробника та його зростання в досягненні міжнародної 
конкурентоспроможності переважно грунтується на ресурсному потенціалі, як у вихідному стані підприємства, так і в динаміці проміжних перспективних станів. Ефективне управління економічною стабільністю та зростанням бізнесу на основі ресурсного комплексу супроводжується його оцінкою, аналізом та прогнозуванням з використанням великої різноманітності абсолютних та відносних показників. Для вдосконалення управління формуванням стійкості та прогресивного розвитку промислового підприємства доцільно використовувати новітні елементи інтелектуалізації інформації та використання відповідного програмного забезпечення. Узагальнено методичний підхід до формування інформаційно-знаннєвого забезпечення інтелектуалізації управління прогресивними змінами на підприємстві. Запропоновано активізувати використання інформаційних систем та технологій управління стійкістю та розвитком промислового підприємства в умовах сучасної інформатизації економіки. Акцентовано на необхідності прискорення таких трансформацій в переробній промисловості продовольчого сегменту для забезпечення результативної якості його розвитку.

Ключові слова: стійкість підприємства, економічна стійкість, фінансова стійкість, прогресивний розвиток, обліково-аналітичне забезпечення, теорія систем, системний аналіз.

\section{СИСТЕМНО-ИНФОРМАЦИОННАЯ МОДЕРНИЗАЦИЯ УПРАВЛЕНИЯ УСТОЙЧИВОСТЬЮ И РАЗВИТИЕМ ПРЕДПРИЯТИЙ ПИЩЕВОЙ ПРОМЫШЛЕННОСТИ}

Аннотация. В статье рассматриваются вопросы экономической устойчивости и прогрессивного развития предприятий пищевой промышленности. Будущее национальной экономики зависит от способности к устойчивому функционированию производственных предприятий в современных экономических условиях, для которых ключевыми проблемами являются жесткая конкуренция и глобальные тенденции на рынке. В этом контексте необходимы научные исследования новейших подходов к формированию и оценке потенциальной устойчивости хозяйствующего субъекта, его анализу и прогнозированию его прогрессивного развития с целью достижения международной конкурентоспособности. В исследованиях системным объектом является ресурсная устойчивость предприятия в тех компонентах, которые его формируют и обеспечивают поступательное развитие предприятия. Обобщение научных поисков ресурсного направления управления формированием потенциала эффективного функционирования и восходящего развития предприятий позволяет выделить следующий состав ресурсов для характеристики сложного системного объекта «устойчивость предприятия»: финансовый, логистический, трудовой, организационный, инновационный, информационный, интеллектуальный. Интеллектуальная поддержка предприятия оказывает большое влияние на успешное решение проблем современного предприятия. Стабильность современного производственного предприятия и его восходящее развитие в достижении международной конкурентоспособности основаны преимущественно на ресурсном потенциале. Эффективное управление экономической стабильностью и восходящим развитием предприятия на основе ресурсного комплекса сопровождается его оценкой, анализом и прогнозированием с использованием широкого спектра абсолютных и относительных показателей.

Ключевые слова: устойчивость предприятия, экономическая устойчивость, финансовая устойчивость, прогрессивное развитие, учетно-аналитическое обеспечение, теория систем, системный анализ. 